\title{
A jogszabályok és a stratégiai tervek környezeti hatásvizsgálatának gyakorlata
}

\author{
Környezeti hatásvizsgálatok - a jogalkotás hatásvizsgálata - \\ vizsgálati elemzés - stratégiai környezeti vizsgálat
}

\begin{abstract}
A jog alapvető funkciója az emberek közötti viszonyok normatív szabályozása, az emberi együttélés rendjének kialakítása. A társadalmi viszonyok szabályozása számos olyan kedvező, illetve kedvezőtlen hatással jár, melyek értékelése a jogalkotó számára elengedhetetlenül szükséges. E vizsgálatok elvégzése mutathatja meg, hogy a jogalkotó által kitüzött szabályozási cél megvalósítható-e - azaz érdemes-e egyáltalán az adott kérdést a jog eszközeivel szabályozni -, és ha igen, a cél elérésére választott normatív eszköz valóban a leghatékonyabb módszert alkalmazza-e. E kérdések megválaszolására szolgál a jogi szabályozás hatásvizsgálata, amely a jogi szabályozás színvonalának állandó javítását, a szabályok érvényesülésének ellenőrzését biztosító módszer. A minőségi jogalkotás megvalósítása és a jogalkotó döntési helyzetének megalapozása érdekében elvégzett hatásvizsgálatok elősegítik a lehetséges alternatívák közötti választást, továbbá a jogalkotói szándékot híven tükröző, követhető, egyszerübb, világosabb jogszabályok megalkotását. Az említett célokhoz kapcsolódó másik fontos feladat a hatályos jogszabályok hatékonyságának ellenőrzése, azaz egy folyamatos hatályosulási vizsgálat, mely egyben információkat szolgáltat a jövőbeli szabályozási koncepciók kidolgozásához.
\end{abstract}

Az említett szempontokat alapul véve több jogtudományi és egyéb, főként gazdasági megközelítést alkalmazó definíció született a hatásvizsgálat fogalmára vonatkozóan. A jogtudományi definíciók közül példaként említhető az a meghatározás, mely szerint „a szabályozás hatásvizsgálata olyan információgyüjtő-elemző folyamat, melynek elsődleges célja a jogszabályok hatékonyságának növelése az előkészítés alatt álló vagy már hatályos szabályok rövid és hosszú távú társadalmi gazdasági, illetve egyéb hatásainak a szabályozás természete által indokolt mértékben történő megvizsgálása, majd az eredmények megalapozottabb jogalkotói döntéshozatal elösegítése érdekében történő összegzése útján”.1

Ehhez hasonló definíciót tartalmaz az előzetes és utólagos hatásvizsgálatról szóló 24/2011. (VIII. 9.) KIM-rendelet (a továbbiakban: hatásvizsgálati rendelet) 2. § (1) bekezdés 2. pontja. Eszerint a hatásvizsgálat „olyan információgyüjtő-elemző folyamat, amelynek elsődleges célja a szabályozás hatékonyságának növelése, mely

\footnotetext{
* Dr. Gyürü Attila környezetjogi elöadó, Nemzeti Környezetügyi Intézet; PhD-hallgató, ELTE Állam- és Jogtudományi Kar Nemzetközi Jogi Tanszék, Budapest, gyurua@gmail.com.

1 KovÁcsy Zsombor - OrBán Krisztián: A jogi szabályozás hatásvizsgálata. Dialóg Campus Kiadó, 2005, 26.
} 
magában foglalja a szabályozás várható következményeinek a szabályozás feltételezett hatásaihoz igazodó részletességben és releváns időtávon történő megvizsgálását, majd az eredmények megalapozott döntéshozatal elösegítése érdekében történő összegzését”. Az említettek (akárcsak az itt nem részletezett, ágazati definíciók) megegyeznek abban, hogy a hatásvizsgálat információgyűjtő és elemző folyamat, mely a szabályozás hatásait és következményeit vizsgálja, a hatékony döntésmegalapozás érdekében.

Tanulmányom célja annak ismertetése, hogy a hatályos jog szerint a jogszabályalkotás során a környezeti hatások vizsgálata miképpen szerepel és mennyiben érvényesül, melyek a legföbb gyakorlati problémák, és melyek a jogfejlesztés lehetséges irányai. Ennek során igyekszem hasznosítani a Jövő Nemzedékek Országgyülési Biztosa Irodájánál (2008-2011), illetve azt követően (2012-) a Nemzeti Környezetügyi Intézetnél szerzett tapasztalataimat.

\section{A hatásvizsgálat alkalmazási köre, típusai, eszközei}

Hatásvizsgálatra általában akkor van szükség, ha egy adott területen felmerül a szabályozás igénye, tehát jogszabály megalkotása szükséges. E szabályalkotás vonatkozhat korábban nem szabályozott „új területekre”, illetve meglévő szabályok módosítására vagy hatályon kívül helyezésére. A jogalkotásra vonatkozó hatályos jogunk ugyanakkor csak bizonyos jogszabályok esetén ír elő hatásvizsgálatot; ilyenek a hatásvizsgálati rendelet szerint a Kormány vagy a miniszter által előterjesztett jogalkotási aktusok. A jogalkotásról szóló 2010. évi CXXX. törvény (a továbbiakban: új Jat.) 17. $§(1)$ bekezdése kiterjeszti a hatásvizsgálati kötelezettséget az önkormányzati rendeletekre is, valamint kimondja, hogy miniszteri rendelet rendelkezhet úgy, hogy az általa meghatározott esetben a közjogi szervezetszabályozó eszköz elökészítője is előzetes hatásvizsgálatot végez. Mindezek alapján elmondható, hogy a köztársasági elnök, az országgyülési képviselö, valamint országgyülési bizottság által előterjesztett törvényjavaslatok esetében egyáltalán nem kötelező hatásvizsgálat lefolytatása.

Amennyiben a jogalkotó új területet kíván szabályozni, úgy kiemelkedő szerephez jut az előzetes hatásvizsgálat, mely egy, a kérdéses területet érintő egyéb szabályokra, illetve esetlegesen külföldi tapasztalatokra építö becslési módszer, az igények rendszerezett, meghatározott szempontok szerinti felmérése, összegyüjtése és becsatornázása. Az előzetes hatásvizsgálat alap- és módosító jogszabályok esetén egyaránt alkalmazható eszköz. Ehhez képest az utólagos hatásvizsgálat egy hatályos jogszabály tényleges alkalmazásának tapasztalatait értékeli és elemzi. Új terület szabályozása esetén, az adott területre vonatkozó legelső jogszabály megalkotását megelőzően értelemszerüen nem beszélhetünk utólagos hatásvizsgálatról, minden más esetben azonban ezen módszer is kiválóan alkalmazható, nemcsak a tapasztalatok értékelésére, hanem azok visszacsatolása révén a szükséges újraszabályozások, illetve dereguláció elökészítésére.

Az egyes hatásvizsgálati eszközök közötti alapvetö különbség, hogy azok a szabályozás által előidézett számszerüsíthető hatások vizsgálatára alkalmazhatók-e, 
avagy a számszerü értékkel általában ki nem fejezhető, úgynevezett nem gazdasági jellegű hatások vizsgálatára alkalmasak. Az egészségügyi, környezeti és társadalmi hatások, illetve magának a jognak a hatékonysága a számszerüsíthetően kevésbé kifejezhető hatások közé tartoznak. Esetükben a számszerüsíthető jellemzők helyett inkább a szubjektív, a nem vagy kevésbé monetarizálható hatások dominálnak. Az, hogy a gazdasági és nem gazdasági jellegủ hatások közül melyik válik hangsúlyossá a vizsgálat során, nagyban függ az ország gazdaságpolitikai felfogásától, illetve a jogi kultúrától. Jellemző például, hogy az angolszász gyakorlat az összes hatás monetarizálására törekszik, és olyan hatásokat is próbál pénzben kifejezni, melyek esetén ez kevésbé lehetséges. Ugyanakkor például az Egyesült Államokban e szemlélet a korábbi évtizedekhez képest sokat finomodott, a monetáris szempontok egyeduralma jelentősen csökkent, a kidolgozott hatásvizsgálati eljárásrendek sokkal inkább átfogó, komplex szemléletű megközelítést alkalmaznak. A kontinentális gyakorlat viszont általában ennél nagyobb szerepet tulajdonít a szubjektív szempontoknak a hatásvizsgálatok során. Az pedig, hogy az említett eszközök közül melyek alkalmazása, illetve kombinációja tekinthető optimálisnak, mindig az egyes hatásvizsgálatok céljainak figyelembevételével dönthető el.

\section{A környezeti hatásvizsgálatok szerepe és sajátosságai}

Ha környezeti hatásvizsgálatról beszélünk, azon a hatályos szabályozás alapján többféle eljárást kell érteni. A környezeti hatások vizsgálata fontos a jogalkotás során is, de ugyanakkor a hatósági jogalkalmazás során is, pl. a környezeti hatásvizsgálati eljárás a környezetvédelmi hatósági eljárások egyik jellemző fajtája. ${ }^{2}$ A környezeti hatásvizsgálatok alapvető jellemzőit az alábbi táblázat mutatja be:

\begin{tabular}{|c|c|c|c|c|}
\hline & $\begin{array}{c}\text { Általános } \\
\text { jogalkotási } \\
\text { hatásvizsgálat }\end{array}$ & $\begin{array}{c}\text { Vizsgálati } \\
\text { elemzés }\end{array}$ & $\begin{array}{c}\text { Stratégiai } \\
\text { környezeti } \\
\text { vizsgálat }\end{array}$ & $\begin{array}{c}\text { Környezeti } \\
\text { hatásvizsgálat }\end{array}$ \\
\hline $\begin{array}{c}\text { Jogszabályi } \\
\text { alapja }\end{array}$ & $\begin{array}{c}\text { Jogalkotási } \\
\text { törvény }\end{array}$ & $\begin{array}{c}\text { Környezetvédelmi } \\
\text { törvény }\end{array}$ & $\begin{array}{c}\text { Környezetvédelmi } \\
\text { törvény és } \\
\text { SKV-rendelet }\end{array}$ & $\begin{array}{c}\text { Környezetvédelmi } \\
\text { törvény és } \\
\text { KHV-rendelet }\end{array}$ \\
\hline Alanya & $\begin{array}{c}\text { A jogszabály } \\
\text { elökészítöje }\end{array}$ & $\begin{array}{c}\text { A törvényjavaslat, } \\
\text { más jogszabály } \\
\text { vagy koncepció } \\
\text { elökészítője }\end{array}$ & $\begin{array}{c}\text { A terv vagy program } \\
\text { elökészítője }\end{array}$ & A kérelmező \\
\hline Célja & $\begin{array}{c}\text { A szabályozás } \\
\text { várható } \\
\text { következményeinek } \\
\text { felmérése és } \\
\text { hatályosulásának } \\
\text { vizsgálata }\end{array}$ & $\begin{array}{c}\text { Az intézkedés } \\
\text { környezetre } \\
\text { gyakorolt hatásainak } \\
\text { vizsgálata és } \\
\text { értékelése }\end{array}$ & $\begin{array}{c}\text { A tervek és } \\
\text { programok várható } \\
\text { környezetei } \\
\text { hatásainak } \\
\text { vizsgálata }\end{array}$ & $\begin{array}{c}\text { A tevékenység } \\
\text { várható környezeti } \\
\text { hatásainak } \\
\text { vizsgálata és } \\
\text { értékelése }\end{array}$ \\
\hline
\end{tabular}

2 A részletes szabályok a környezeti hatásvizsgálati és az egységes környezethasználati engedélyezési eljárásról szóló 314/2005. (XII. 25.) Korm. rendeletben találhatók. 
A táblázat alapján jól látható a különbség a szabályozási célú, jogszabályi vagy egyéb program, illetve terv formában megjelenő aktusok, és az egyedi hatósági ügyre vonatkozó hatásvizsgálatok között. A részletek említése nélkül meg kell jegyezni, hogy az egyedi ügyekben elvégzett hatásvizsgálat legfőbb sajátossága, hogy konkrét tevékenységek környezetvédelmi engedélyezési eljárásaihoz kapcsolódik, és magyar specialitásként - környezetvédelmi törvényünk alapján, a többi vizsgálattal ellentétben - ügydöntő jelentőségü. Említést kell tenni még azon speciális hatásvizsgálatokról, amelyek egy-egy sajátos szakterületre koncentrálnak. Ilyen például a településrendezési eljárásokhoz kapcsolódó örökségvédelmi hatásvizsgálat ${ }^{3}$ vagy a természetvédelmi eljárások sajátos fajtája, a Natura 2000 területekkel kapcsolatos hatásbecslési eljárás. ${ }^{4}$

A környezeti hatások elemzése a hatásvizsgálatok körében a legmagasabb szinten kidolgozott módszertani területek egyike. ${ }^{5}$ Ennek indoka elsősorban abban keresendő, hogy a rohamos gazdasági fejlődés és a globalizáció a 20. század folyamán felvetette a kérdést: milyen módszerek állnak rendelkezésre ahhoz, hogy a bolygónkat terhelő kedvezőtlen hatások ne növekedjenek? A legjellemzőbb veszélyek, mint például a globális felmelegedés, sivatagosodás, savas eső, tengerek szennyezése stb. hatásainak csökkentése érdekében, az egyes országok gazdaság- és környezetpolitikái, illetve jogrendszerei különféle válaszokat kívántak adni. Tekintettel a kérdés jelentőségére, az együttmüködés nemcsak nemzeti, hanem regionális és nemzetközi szinten is egyre fontosabb lett. E környezetben került sor az ENSZ 1972-es környezeti világkonferenciájára Stockholmban, ahol a résztvevők nyilatkozatot fogadtak el a környezetvédelem alapelveiröl és feladatairól. Létrehozták egyúttal az ENSZ Környezetvédelmi Programot és annak intézményrendszerét, melynek célja az ENSZ környezetvédelmi tevékenységének koordinációja, a környezetvédelmi politika nemzeti és nemzetközi szintű fejlesztése. Ezt követően került sor az 1992-es Riói Konferenciára és az ott elfogadott deklarációra, melynek 11. alapelve konkrétan megfogalmazza a hatékony környezetvédelmi jogszabályok alkotásának kötelezettségét, illetve a 17. alapelv említi a környezetvédelmi hatásvizsgálat készítésének kötelezettségét, amennyiben az adott tevékenység kedvezőtlen környezeti hatásokkal jár. Példálózó jelleggel érdemes még megemlíteni az országhatárokon átterjedő környezeti hatások vizsgálatáról szóló, 1991-ben aláirt Espooi Egyezményt, ${ }^{6}$ amely részletes követelményeket állít fel a környezeti hatásvizsgálat nemzeti és nemzetközi szerepének növelése érdekében; valamint a környezeti ügyekben az információhoz való hozzáférésről, a nyilvánosságnak a döntéshozatalban való részvételéről és az igaz-

3 Az örökségvédelmi hatástanulmánnyal kapcsolatos szabályokat a kulturális örökség védelméröl szóló 2001. évi LXIV. törvény, valamint az örökségvédelmi hatástanulmányról szóló 4/2003. (II. 20.) NKÖM-rendelet tartalmazza.

${ }^{4}$ A Natura 2000 területekkel kapcsolatos hatásbecslés szabályait az európai közösségi jelentőségü természetvédelmi rendeltetésű területekröl szóló 275/2004. (X. 8.) Korm. rendelet tartalmazza.

5 KovácsY-OrBán: i. m., 30.

${ }^{6}$ Az országhatáron átterjedő környezeti hatások vizsgálatáról szóló, Espooban (Finnország), 1991. február 26. napján aláirt egyezmény kihirdetéséről szóló 148/1999. (X. 13.) Korm. rendelet. 
ságszolgáltatáshoz való jog biztosításáról szóló, 1998-ban aláírt Aarhusi Egyezményt. ${ }^{7}$ Utóbbi dokumentum elsősorban a környezetvédelmi szempontok döntéshozatalba való integrálását, illetve a hatóságok ezzel kapcsolatos munkájának civil kontrollját szabályozza, azonban szervesen kapcsolódik a hatásvizsgálat kérdéséhez is, mivel elöírásokat tartalmaz a hatásvizsgálat-köteles tevékenységekkel kapcsolatban, a társadalmi részvétel érvényesülése érdekében. A cél ez esetben is ugyanaz: a környezetvédelmi szempontok jelentőségüknek megfelelö hangsúllyal szerepeljenek minden, a környezetet érintő jogalkotói és jogalkalmazói döntéshozatal során. ${ }^{8}$

A környezeti hatásvizsgálat eszköztára tehát más hatásvizsgálatokhoz hasonlítva is igen kifinomult, ami az elöbbiekben elmondottak mellett a környezetjog sajátosságaival is igazolható. A környezetjog egyik fő jellegzetessége ugyanis, hogy igen komplex jogterület, mely eszközeit a közjog és a magánjog manapság egyre relatívabb elkülönülésétől függetlenül választja. A prevenció elvét érvényesíti, aminek indoka, hogy a környezetet érintő tevékenységek kedvezőtlen hatásai (pl. a környezeti elemek szennyezése) a tevékenység megkezdését követően jóval nehezebben korrigálhatók, így más jogterületekkel szemben egy a környezetet érintő jogszabály megalkotásakor a döntés esetleges hatásait a lehető legpontosabban kell értékelni. Ezt mondta ki az Alkotmánybíróság a környezetvédelmi alaphatározatnak tekintett 28/1994. (V. 20.) $A B$-határozatban, miszerint az egészséges környezethez való jog sajátosságai miatt a környezethez való jog védelmének eszközei között a megelőzésnek elsőbbsége van, hiszen a visszafordíthatatlan károk utólagos szankcionálása nem tudja helyreállítani az eredeti állapotot. Mivel a szabályozás olyan elemeket érint (egészség, környezet vagy a természet állapota), melyek változásai jogalkotási aktussal nehezen irányíthatók, ezen területen a szabályozás összetett szempontrendszer szerint kell hogy megvalósuljon.

Sajátosságként említendők - mind a környezetvédelmi vonatkozású jogszabályok, mind pedig a hatósági döntések esetén - a nemzetközi vonatkozások is, tekintettel arra, hogy a környezet használatával járó káros hatások igen sok esetben több ország területét érintik. A globális szemlélet és az ahhoz kapcsolódó lokális cselekvés tehát alapvető követelmény; ezt tükrözi a számos nemzetközi és regionális környezetvédelmi egyezmény és a nemzetközi intézmények szakosított testületei, s e szemléletet kell érvényesíteni a hatásvizsgálatok során is.

Említést kell tenni még egy elvi kérdésröl, nevezetesen, hogy a környezeti hatásvizsgálat a szük (hagyományos) értelemben vett környezetvédelmi és természetvédelmi szempontok figyelembevételére, vagy pedig az annál jóval szélesebb értelemben vett, fenntarthatósági szempontok értékelésére és vizsgálatára kell hogy irányuljon. Ennek eldöntése környezetpolitikai kérdés, azonban az egyértelmü, hogy a fenntarthatósági szempontok és indikátorok által meghatározott környezeti hatásvizsgálat jóval átfogóbb és bonyolultabb hatásvizsgálati elemzést tesz szükségessé, mely

A környezeti ügyekben az információhoz való hozzáférésről, a nyilvánosságnak a döntéshozatalban történő részvételéröl és az igazságszolgáltatáshoz való jog biztosításáról szóló, Aarhusban, 1998. június 25-én elfogadott Egyezmény kihirdetéséről szóló 2001. évi LXXXI. törvény.

8 Az Aarhusi Egyezmény „pillérei” az információhoz való hozzáférés, a döntéshozatalban való részvétel, az igazságszolgáltatáshoz való jog biztosítása és a részvételre képesítés. 
bizonyosan alkalmasabb a környezetpolitikai szempontok integrálására az egyéb ágazati politikákba. ${ }^{9}$

A kérdés megválaszolásának alapja, a fenntartható fejlődés vagy fenntarthatóság fogalma, nevezetesen, hogy „a fenntartható - harmonikus - fejlödés a fejlődés olyan formája, mely úgy elégíti ki a jelen igényeit, hogy nem fosztja meg a jövő generációját saját szükségletei kielégítésének lehetőségétől". ${ }^{10}$ Más szavakkal: a fenntartható fejlődés vagy fenntarthatóság lényege egy hosszabb távon követhető, komplex fejlődési irányvonal meghatározása. ${ }^{11} \mathrm{~A}$ fenntarthatóság a környezeti és természeti érdekek figyelembevételénél jóval többet jelent, hiszen vannak gazdasági és társadalmi aspektusai (pillérei) is.

Hazánkban a fenntarthatóság a jogszabályok környezeti hatásvizsgálata során ellentmondásosan jelenik meg. Az új Jat. az elődjénél jóval részletesebben szabályozza a hatásvizsgálat jogintézményét, annak végrehajtási rendelete, valamint a hatásvizsgálati útmutató pedig részletesen bemutatja a hatásvizsgálati szempontrendszert, melyet a jogalkotónak alkalmaznia kell. ${ }^{12}$ Figyelemre méltó, hogy a hatásvizsgálati rendelet szövege a környezeti és természeti hatásokkal foglalkozik, azonban az annak mellékletét képező hatásvizsgálati lap a fenntartható fejlődés fogalmát használja, és ezáltal az említett, értékorientált szempontrendszerre utal. Ténylegesen azonban ezenkívül egyéb támpontot a hatásvizsgálati lap sem ad, így végeredményben csak a környezeti és természeti hatások (elszigetelt) vizsgálatára alkalmas.

Összegezve tehát az elmondottakat, az új Jat. által meghatározott hatásvizsgálati rendszer nem határoz meg fenntarthatósági indikátorokat, szinte azonos fogalmakként használja a fenntarthatóság és a környezeti, illetve természeti hatások vizsgálatát. Véleményem szerint az adott jogszabályi hatásvizsgálat akkor elégítheti ki a fenntarthatósági szempontok érvényesítésének követelményeit, ha az a fenntarthatóság pilléreit (gazdasági, társadalmi, környezeti) együttesen, egymásra tekintettel képes értékelni.

\section{Környezeti hatásvizsgálatok a jogalkotásban}

\section{1. Általános jogalkotási hatásvizsgálat}

Az általános jogalkotási követelmények természetesen a környezetvédelmi jogalkotásra is érvényesek. Az új Jat. 17. § (1) bekezdése a jogszabály előkészítőjének feladatául szabja - a jogszabály feltételezett hatásaihoz igazodó részletességű előzetes hatásvizsgálat elvégzését, valamint az eredményről a Kormánynak, illetve a helyi önkormányzat képviselö-testületének a tájékoztatását. A 21. § (1) bekezdése

9 A szük értelemben vett környezetvédelmi és természetvédelmi szempontú hatásvizsgálat, valamint a szélesebb értelemben vett fenntarthatósági szempontokat értékelő hatásvizsgálattal kapcsolatban lásd FODOR László: Fenntarthatósági indikátorok a jogi szabályozás hatásvizsgálatában, Pázmány Law Working Papers, 2012/4.

10 Az ENSZ Környezet és Fejlődés Világbizottság „Közös Jövőnk” címmel készített jelentése.

11 A fogalom az 1980-as évek elején jelent meg a nemzetközi szakirodalomban.

12 A hatásvizsgálati útmutató elérhető a http://hatasvizsgalat.kormany.hu honlapon. 
szerint pedig a miniszter folyamatosan figyelemmel kíséri a feladatkörébe tartozó jogszabályok hatályosulását, és szükség szerint lefolytatja a jogszabályok utólagos hatásvizsgálatát, összevetve a szabályozás megalkotása idején várt hatásokat a tényleges hatásokkal. Az utólagos hatásvizsgálat lefolytatása adott esetben a Magyar Nemzeti Bank elnöke, az önáló szabályozószerv vezetője, vagy önkormányzati rendelet esetén a jegyző kötelezettsége. A hatásvizsgálattal kapcsolatos részletszabályokat a hatásvizsgálati rendelet, valamint a Közigazgatási és Igazságügyi Minisztérium által készített hatásvizsgálati útmutató tartalmazza. Az e követelményeknek való egységes megfelelés érdekében hatásvizsgálati lap alkalmazását írják elő, mely a lehetséges módszerek kiválasztásához is szempontokat ad. A szabályozás tehát az egységesítés igényét tartja szem előtt, azonban bizonyos kérdések nyitottak maradtak. Itt és most sem kapunk választ a köztársasági elnök, az országgyűlési képviselő és az országgyülési bizottság által előterjesztett törvényjavaslatok helyzetére. Ez a kérdés a gyakorlatban leginkább az országgyülési képviselők törvényjavaslatai alapján elfogadott törvények gyakran hiányos előkészítése miatt bír jelentőséggel. A korábbi Jat. idejében is felmerült másik problémára ugyanakkor, miszerint egy javaslat az elfogadásáig változásokon eshet keresztül, amelyek az eredeti tervezethez képest egészen eltérő hatásokat indukálhatnak, már reflektál, amennyiben előírja a vizsgálat megismétlését. ${ }^{13}$

A jogalkotási gyakorlat azt mutatja, hogy az új Jat. szerinti hatásvizsgálatok közül előzetes hatásvizsgálat szinte minden esetben készül, azonban a hatásvizsgálati lap tartalma gyakran hiányos, az információk általánosak és pontatlanok, gyakran politikai üzeneteket fogalmaznak meg, a várható hatások tényleges értékelése helyett. A hatásvizsgálat formai követelményeinek ez a gyakorlat megfelel, azonban a tartalmi követelmények szempontjából aggályos. Az utólagos hatásvizsgálattal kapcsolatosan elmondható, hogy ebben az esetben sem a formai, sem pedig a tartalmi követelmények nem teljesülnek, mivel önálló, utólagos hatásvizsgálat a gyakorlatban szinte egyáltalán nem készül. Azt legfeljebb az előzetes hatásvizsgálattal együtt alkalmazza a jogalkotó, ha a hatályos szabályozás helyett új szabályok megalkotása, a hatályos szabályok módosítása vagy hatályon kívül helyezése szükséges. Említést kell tenni a tartalmi felülvizsgálat gyakorlati alkalmazásáról, mely a jogalkotás során folyamatosan érvényesül, azonban, a hivatkozottaknak megfelelően nem célja a jogszabályok különböző hatásainak tényleges értékelése, sokkal inkább a jogalkotási, föként jogszabály-szerkesztési követelmények érvényesítése.

Az új Jat. szerinti általános hatásvizsgálatnak fentiek szerint - a gazdasági, egészségügyi, adminisztrációs stb. hatások mellett - lényegi részét képezi a környezeti hatások vizsgálata. Ehhez képest több tekintetben is hasonló, ám szektorspecifikus hatásvizsgálati forma a környezetvédelmi törvény által szabályozott vizsgálati elemzés, illetve a stratégiai környezeti vizsgálat, amelyekröl az alábbiakban lesz szó. 


\subsection{A vizsgálati elemzés}

\subsubsection{Jogszabályi alapok}

A jogalkotási hatásvizsgálat sajátos fajtája a környezet védelmének általános szabályairól szóló 1995. évi LIII. törvény (Kvt.) 43. §-ában szabályozott vizsgálati elemzés, amely a környezetvédelemmel összefüggő jogszabályok, valamint (a környezeti vizsgálat alá tartozók kivételével) az országos és regionális jelentőségű koncepciók környezetre gyakorolt hatásainak a vizsgálatára és értékelésére irányul. A 44. § (1) bekezdés alapján a környezetre gyakorolt hatások mellett ki kell terjednie e vizsgálatnak arra is, hogy a hazai feltételek mennyiben adottak a tervezett intézkedések bevezetéséhez (a közigazgatási szervek mennyiben felkészültek a végrehajtásra; a megvalósításhoz az állami, pénzügyi, szervezeti és eljárási feltételek rendelkezésre állnak-e), vagy hogy a javaslat mennyiben jelent eltérést a nemzetközileg általánosan elfogadott megoldásoktól. A vizsgálati kötelezettség itt is az előkészítőt terheli, mégpedig azon törvény, kormányrendelet, miniszteri rendelet, illetőleg döntés vonatkozásában, amely a környezeti elemekre, a környezet minőségére, vagy azzal összefüggésben az emberi egészségre hatást gyakorol. A környezetvédelemmel összefüggő gazdasági szabályozóeszközök bevezetése, továbbá a jelentős módosítások esetében a vizsgálati elemzés nem maradhat el. A törvény tehát definiálja a vizsgálati elemzés fogalmát, annak hatályát, megkülönböztetve a stratégiai környezeti vizsgálattól, meghatározza a környezetvédelmi relevanciával rendelkező jogszabály föbb sajátosságait, és külön kötelezettségként mondja ki a gazdasági szabályozóeszközökhöz kapcsolódó elemzési kötelezettséget. Kiterjesztően értelmezi ugyanakkor a környezetvédelem kifejezést, és valamennyi olyan jogszabály esetén kimondja e kötelezettséget, mely környezetvédelmi érdekeket valamilyen módon érint, függetlenül attól, hogy melyik ágazatot célozza elsődlegesen szabályozni. Egyértelműen elválasztható e hatásvizsgálat az SKV-töl, tekintettel annak tárgyi hatályára. Sokkal relatívabb viszont a kapcsolat az általános, új Jat. szerinti hatásvizsgálat környezeti részét illetően. Az elhatárolási kérdések ellenére is védhetőnek tünik azonban az a vélemény, miszerint itt minőségileg többről van szó, azaz konkrétabb követelmények elöírásáról minden olyan jogszabály tervezete esetén, melynek környezetvédelmi relevanciája lehet.

Az új Jat. szerinti hatásvizsgálati útmutató megkísérel választ adni az elhatárolás kérdésére, mely szerint az előterjesztőnek elsőként azt kell vizsgálnia, hogy a jogszabály az SKV-rendelet hatálya alá tartozik-e, illetve azt kell eldönteni, hogy a Natura 2000 területekre jelentős hatást gyakorol-e. Ezt követően kell vizsgálni, hogy környezetvédelemmel összefüggő jogszabálynak minősül-e, és vizsgálati elemzés hatálya alá tartozik, vagy pedig nem minősül ilyen jogszabálynak, és akkor a hatásvizsgálati rendelet szabályai szerint vizsgálandók annak a környezetre és természetre gyakorolt hatásai. Véleményem szerint mindezek ellenére felmerülnek az elhatárolással kapcsolatos gyakorlati kérdések, melyek megoldása alaposabb elemzést igényel. 


\subsubsection{A vizsgálati elemzés gyakorlati alkalmazása}

A szabályozásból kétségtelenül adódó párhuzamosságok a gyakorlatban azt jelentik, hogy a jogalkotó az említett általános hatásvizsgálati lap megfelelő részének kitöltésével általában letudja e kötelezettségét, és komplex, a Kvt. 44. § (1) bekezdésében található követelményeket is magában foglaló elemzés szinte egyáltalán nem készül, vagy hasonlóval legfeljebb a jelentősebb környezetvédelmi jogszabályoknál lehet találkozni. ${ }^{14}$

A tartalmi követelmények mellett a 44. § (2) bekezdése kimondja, hogy a vizsgálati elemzés benyújtásának feltétele a véleményezésre való megküldése az Országos Környezetvédelmi Tanácsnak (OKT), amely ezt követően véleményét a döntésre jogosult szervnek maga terjeszti elő. Az OKT véleményezési jogkörének érvényesülése a vizsgálati elemzéséhez hasonlóan alakul, azaz az előterjesztők sok környezetvédelmi tárgyú jogszabályt nem küldenek meg véleményezésre. ${ }^{15}$ Külön kérdésként jelenik meg a bizottsági indítványok és az egyéni képviselői indítványok helyzete, és azoknak a vizsgálati elemzés követelményeivel való kapcsolata. Egyrészt azért, mert az említett indítványok esetében a gyakorlatban elmarad a társadalmi véleményezés és a közigazgatási egyeztetés, így ezen indítványok jellemzően akkor sem kerülnek az OKT elé, ha azok átfogó jellegükből adódóan jelentősen érintik a környezet érdekeit. Ebben a jogszabályi keretek is hibásak, mivel a Kvt. hatályos rendelkezései az OKT-t a Kormány javaslattevő, tanácsadó és véleményező szerveként határozzák meg, és eleve nem tisztázzák azt a helyzetet, ha a törvényjavaslat az említett formákban készül.

Az Alkotmánybíróság több esetben is foglalkozott a jogalkotási eljárás során lefolytatandó egyeztetési, illetve véleményeztetési kötelezettség elmulasztása alkotmányosságának kérdésével. ${ }^{16} A 30 / 2000$. (X. 11.) AB-határozatban környezetvédelmi tárgyú jogszabállyal kapcsolatban állapította meg formai szempontok alapján az alkotmányellenességet, a véleményeztetési kötelezettség garanciális szabályainak be nem tartása miatt.

A nehéz tehergépkocsik közlekedésének korlátozásáról szóló 111/1995. (IX. 21.) Korm. rendelet módosításáról szóló 99/1997. (VI. 11.) Korm. rendelet alkotmányellenességének kimondása során a testület részletesen elemezte a jogalkotási eljáráshoz kapcsolódó egyeztetési kötelezettség követelményét. Kimondta, hogy az Alkotmány 36. §-a szerint a Kormány feladatának ellátása során együttmüködik az érdekelt társadalmi szervekkel, azonban az e paragrafus, valamint a Jat. által előírt általános - minden jogalkotási aktusra vonatkozó - egyeztetési kötelezettségböl nem következik, hogy annak elmulasztása automatikusan a jogszabály közjogi érvénytelenségét idézné elő, ellenkező esetben a jogalkotó nem tudná az Alkotmányból adódó jogalkotási feladatait ellátni, mivel beazonosíthatatlan és felleltározhatatlan lenne

14 A hatásvizsgálati útmutató szerint, amennyiben külön jogszabálynak megfelelő tartalommal hatásvizsgálat készül, úgy annak eredményét a hatásvizsgálati lapon meg kell jeleníteni, a dokumentáció az előterjesztés hatásvizsgálatának a mellékletét képezi.

15 Általánosságban elmondható, hogy az OKT-hoz 27-33 előterjesztés érkezik évente, 10 ülést tart, ahol 2025 előterjesztést tárgyal a Tanács és 10-12 állásfoglalást készít.

16 16/1998. (V. 8.) AB-határozat, 39/1999. (XII. 21.) AB-határozat, 10/2001. (IV. 12.) AB-határozat, 7/2004. (III. 24.) $A B$-határozat. 
azon érdekképviseleti szervek száma, melyeknek az egyeztetési eljárásba való bevonása szükséges lehet. Erre tekintettel alakította ki az AB a „közhatalmi jelleg” kritériumát, kimondva, hogy a jogszabály által kifejezetten és konkrétan megnevezett, egyetértési, illetve véleményezési jogkörrel rendelkező szervezetek - a demokratikus döntéshozatali eljárásban betöltött szerepük miatt, az egyeztetési kötelezettség vonatkozásában - közhatalminak, így a jogalkotó számára megkerülhetetlennek minösülnek. A szóban forgó jogszabály alkotmányosságának értelmezésekor a Tanács közhatalmi jellegének vizsgálatára nem volt szükség, ugyanis a jogalkotó véleményeztetési kötelezettségét nem az Alkotmány 36. §-a vagy a Jat. rendelkezései alapozták meg, hanem a Kvt. 44. § (2) bekezdése, ami ez esetben egy speciálisabb, erősebb érvényességi követelményt jelent. $E$ kritériumot a taláros testület azóta is több, nem környezetvédelmi tárgyú határozat során alkalmazta. ${ }^{17}$

A „közhatalmi jelleg” kritériuma mellett az AB azonban másik feltételt is megjelölt, melynek megvalósulása az eseti mérlegelés során fontos szempont az alkotmányellenesség vizsgálatában; nevezetesen, hogy a jogalkotási eljárás általános és speciális szabályainak figyelmen kívül hagyása egyben az Alkotmány valamely rendelkezésébe is ütközzön, azaz valamely alapvető jogot sértsen, vagy annak érvényesülését közvetlenül veszélyeztesse.

A 30/2000. (X. 11.) AB-határozatban kimondottak szerint „ha külön törvény - a jelen esetben a Kvt. - ír elő konkrét és intézményesített véleménykérési kötelezettséget, akkor annak elmulasztása olyan, a jogalkotási eljárásban elkövetett súlyos szabálytalanságnak minősülhet, amely adott esetben a jogállamiság alkotmányos követelményét közvetlenül veszélyezteti, és a törvénysértó módon alkotott jogszabály közjogi érvénytelenségét eredményezheti. Azt a kérdést, hogy a külön törvényekben meghatározott jogalkotási eljárási szabály megszegése súlyosságánál fogva adott esetben eléri-e az alkotmánysértés szintjét, az Alkotmánybiróságnak eseti mérlegeléssel kell eldöntenie."

$A z A B$ szerint tehát az OKT véleménye beszerzésének elmulasztása közjogi érvénytelenség kimondásának alapja lehet, azonban e döntés precedens jellege vitatható, tekintettel arra, hogy hasonló tárgyban további határozatot az AB nem hozott. A kérdéssel - azaz a társadalmi szervezetek és érdekképviseleti szervek jogalkotásban való részvételével és véleményezési jogával - ugyan több alkalommal foglalkozott, ${ }^{18}$ azonban alkotmányellenességet közjogi érvénytelenségre hivatkozva csak az említett esetben mondott ki konkrétan e logika alapján, környezetvédelmi tárgyú ügyben. ${ }^{19} \mathrm{Az}$ alkotmánybírósági döntések precedensértékének kimondásához azt kell elsősorban figyelembe venni, hogy az AB milyen gyakran hivatkozik saját döntéseire más határozataiban, azoktól kifejezetten vagy ténylegesen eltér-e. Az elmondottak alapján ez a jelen esetben nem áll fenn, többek között ezért döntött úgy a jövő nemzedékek országgyülési biztosa, hogy 2009-ben a telepengedély, illetve a telep léte-

17 10/2001. (IV. 12.) AB-határozat, 7/2004. (III. 24.) AB-határozat, 124/2008. (X. 14.) AB-határozat.

18 496/B/1990. AB-határozat, 30/1991. (VI. 5.) AB-határozat, 14/1992. (III. 30.) AB-határozat, 54/1996. (XI. 30.) AB-határozat, 50/1998. (XI. 27.) AB-határozat, 39/1999. (XII. 21.) AB-határozat.

19 A 30/2000. (X. 11.) AB-határozatot követő joggyakorlat visszatért ahhoz az irányvonalhoz, miszerint a véleményezési jog megsértése nem feltétlenül jelenti a jogszabály alkotmányellenességét. Erre példa a 7/2004. (III. 24.) AB-határozat, a 651/B/2006. AB-határozat, valamint a 87/2008 (VI. 18.) AB-határozat. 
sítésének bejelentése alapján gyakorolható egyes termelő- és egyes szolgáltató tevékenységekről, valamint a telepengedélyezés rendjéről és a bejelentés szabályairól szóló 358/2008. (XII. 31.) Korm. rendelet alkotmányellenessége kimondása érdekében fordul az Alkotmánybírósághoz. A Biztos által hivatkozott érvelés alapja többek között az említett döntés által kialakított jogelv, azazhogy alkotmányellenes helyzetet teremt a jogalkotó azáltal, ha egy környezetvédelmi relevanciájú jogszabály kidolgozásának folyamatában elmulasztja a közhatalmi jellegü, külön jogszabályban nevesített OKT véleményét kikérni, és ez egyben egy konkrét alkotmányos alapjog, jelen ügyben például az Alkotmány 18. §-a szempontjából is sérelmes. ${ }^{20}$

Összegezve az elmondottakat, legalább két jelentős kérdést kell megfontolni a vizsgálati elemzés gyakorlati érvényesülésével kapcsolatosan: az egyik, hogy annak elmulasztása, illetve leginkább az annak részét képező véleményeztetési kötelezettségről szóló előírás sérelme milyen „szankciók” alkalmazását teszi lehetségessé. E téren tehát a különféle jogvédő szervek, így leginkább az Alkotmánybíróság és az ombudsman gyakorlata fejleszthető. A másik kérdés pedig a vonatkozó jogszabályi keretek esetleges alakításának iránya, azazhogy milyen módon lehetne rendezni a jelenleg az új Jat. által szabályozott hatásvizsgálat környezeti része és a Kvt. szerinti vizsgálati elemzés közötti párhuzamosságokat, és biztosítani azok tényleges alkalmazását. A kérdés azért is releváns, mivel az új Jat. igen részletes szabályozást kíván adni a hatásvizsgálatokat illetően.

Véleményem szerint megfontolandó lett volna olyan szabályozást kialakítani, mely valamilyen formában integrálja a különálló, azonban tárgyát tekintve gyakorlatilag párhuzamos szabályozást úgy, hogy az a minőségi jogalkotás követelményeit is kielégítse, és a környezetvédelmi érdekek megfelelő érvényesítését is biztosítsa. A hatályos szabályok szerint a jogalkotónak az új Jat. szerinti előzetes hatásvizsgálatot, utólagos hatásvizsgálatot, a stratégiai környezeti vizsgálatot, valamint a vizsgálati elemzést kell alkalmaznia, azonban az utólagos hatásvizsgálat kivételével ezen hatásvizsgálatok célja és tartalma jelentős párhuzamosságokat mutat. A stratégiai környezeti vizsgálat különállása indokolható sajátos jellegével, hatályával, mivel az nemcsak jogszabályoknál, hanem különféle terveknél és programoknál is alkalmazandó, és az Európai Unió által előírt kötelezettségen alapul. Az előzetes hatásvizsgálat és a vizsgálati elemzés integrálása azonban gyakorlati szempontból is előnyös és hatékony lenne, valamint egyértelmü, világos hatásvizsgálati rendszert alapozhatna meg. ${ }^{21}$

20 Ennek felel meg a hatályos Alaptörvény XXI. cikk (1) bekezdése. Tekintettel arra, hogy az Alaptörvény hatálybalépésével az ombudsmani rendszer átalakult, és az Alkotmánybíróság eljárásával kapcsolatos szabályok módosultak, az indítványt az alapvető jogok biztosa - módosított tartalommal - ismételten benyújtotta.

21 Az átalakításhoz szempontokat ad Fodor: i. m. 


\subsection{A stratégiai környezeti vizsgálat}

\subsubsection{Jogszabályi alapok}

A stratégiai környezeti vizsgálatok uniós szabályait a bizonyos tervek és programok környezetre gyakorolt hatásainak vizsgálatáról szóló 2001/42/EK irányelv (a továbbiakban: SKV-irányelv) tartalmazza. E jogszabályt a Kvt. 43. § (1)-(7) bekezdése, valamint az egyes tervek, illetve programok környezeti vizsgálatáról szóló 2/2005. (I. 11.) Korm. rendelet (a továbbiakban: SKV-rendelet) ültette át a hazai jogba.

Az irányelv jogalapját az Európai Unió működéséről szóló szerződés 191. cikke (az EK Szerződés korábbi 174. cikke) adja, amely úgy rendelkezik, hogy az unió környezetpolitikájának hozzá kell járulnia többek közt a környezet minőségének megóvásához, védelméhez és javításához, az emberi egészség védelméhez, valamint a természeti erőforrások körültekintő és ésszerủ hasznosításához, továbbá az elővigyázatosság elvén kell alapulnia. A Szerződés 11. cikke (a korábbi 6. cikk) meghatározza, hogy a környezetvédelmi követelményeket - különösen a fenntartható fejlődés előmozdítására tekintettel - be kell illeszteni az uniós politikák és tevékenységek meghatározásába.

A Szerződés által előirányzott komplex, a környezetvédelmi érdekek figyelembevételén alapuló, az integráció elvét tiszteletben tartó megközelítés jegyében született tehát meg az SKV-irányelv, amelynek célja, hogy a környezet magas szintű védelmét biztosítsa, és hogy hozzájáruljon a környezeti szempontok beillesztéséhez a tervek és programok kidolgozásába és elfogadásába. Ez a fenntartható fejlődést segíti elö, annak biztosításával, hogy az irányelvnek megfelelően környezeti vizsgálatot végeznek egyes, a környezetre valószínüleg jelentős hatással járó tervek és programok vonatkozásában. E prioritások elérése érdekében a jogalkotó az SKV-vizsgálatot az európai uniós jog alapján elvégzendő más vizsgálati rendszerekhez igazította hozzá, biztosítva ezzel az esetleges párhuzamosságok elkerülését, illetve a szabályok harmonizációját. Témánk szempontjából a legérdekesebbek az SKV-rendeletnek a hatállyal és az alapfogalmakkal kapcsolatos rendelkezései, melyeket az alábbiakban ismertetek, majd vázlatosan bemutatom a hazai alkalmazás jellemző hiányosságait.

A magyar jogban az SKV hatályát a Kvt. 43. § (4) bekezdése határozza meg. Az kiterjed a környezetre várhatóan jelentős hatást gyakorló (külön jogszabályban meghatározott ${ }^{22}$ ) tervekre, illetve programokra, amelyek kidolgozását jogszabály, illetve országgyülési, kormány- vagy helyi önkormányzati határozat írja elő, és amelyeket közigazgatási szerv (ideértve a közigazgatási feladatot ellátó nem közigazgatási szervet is) dolgoz ki vagy fogad el, illetőleg amelyeket a Kormány terjeszt az Országgyülés elé elfogadásra. Az egyik legérdekesebb kérdés, hogy az SKV miként viszonyul a környezeti hatásvizsgálathoz. A környezeti vizsgálati, környezeti hatásvizsgálati szakirodalom egyik elöfeltevése ugyanis, hogy létezik egy döntéshozatali piramis

22 Az SKV-rendelet szerint idetartoznak a különféle területi, településrendezési, vízgyűjtő-gazdálkodási, közúthálózat-fejlesztési tervek, illetve egyéb tervek és programok, amelyek pl. a mezőgazdaság, energetika, ipar, elektronikus hírközlés, idegenforgalom, regionális fejlesztés stb. számára készülnek, és keretet szabnak olyan tevékenységek vagy létesítmények jövőbeli hatósági engedélyezése számára, amelyek a környezeti hatásvizsgálatról szóló külön jogszabály mellékletében vannak felsorolva, vagy a külön jogszabályban meghatározott Natura 2000 területre jelentős káros hatással lehetnek. 
(hierarchia), amelynek a csúcsán a stratégiai elképzeléseket, koncepciókat tartalmazó szakpolitikák, közepén az ezek megvalósítását megalapozó, már konkrétabban kifejtett tervek, programok vannak, alul pedig a tényleges, fizikai megvalósítást jelentő projektek (tervezése, engedélyezése). Az egyes szintek hierarchikus kapcsolatban vannak egymással, egymásra épülnek, azaz a felsőbb szint befolyásolja az alatta lévőt. ${ }^{23}$ A tervek, programok és a projektek vonatkozásában ugyanez a kiindulópont tükröződik az SKV-rendeletben. A rendelet a hatályt, az alkalmazást illetően úgy fogalmaz, hogy - egyéb feltételek mellett - olyan tervekre és programokra állhat fenn a környezeti vizsgálati kötelezettség, amelyek az egyes projektek jövőbeli engedélyezése számára keretet szabnak. Ennek nyilvánvaló következménye, hogy a rendelet hatálya alá tartozó tervek, programok környezeti vizsgálata elvileg megelőzi a terv, program által befolyásolt projektek engedélyezési eljárásait, így a környezeti hatásvizsgálati eljárást is, amennyiben az szükséges.

További tisztázandó kérdés, hogy mi tekinthető tervnek és programnak. ${ }^{24} \mathrm{~A}$ magyar jogszabályok erre külön fogalmi elhatárolást nem adnak, a Kvt. és az SKV-rendelet a tervek és programok fogalmakat a hatállyal együtt rendezi. Az SKV jogalkotással való kapcsolata a leghatározottabban a településrendezésnél mutatkozik meg. Az épített környezet alakításáról és védelméről szóló 1997. évi LXXVIII. törvény (a továbbiakban: Étv.) 7. § (3) bekezdése szerint településrendezési eszköz a településfejlesztési koncepció és a településszerkezeti terv, melyet a képviselö-testület határozattal állapít meg, valamint a helyi építési szabályzat és a szabályozási terv, melyet a képviselő-testület rendelettel állapít meg. Az önkormányzati rendelet Magyarország Alaptörvényének T) cikk (2) bekezdése alapján jogszabálynak minősül.

Ez esetben tehát sajátos tartalmú jogszabályról beszélhetünk, melynek elfogadása is sajátos rendben történik. Ennek a jogalkotási eljárásnak a keretét az Étv. 9. §-a adja, melynek jelentőségével és sajátosságaival az Alkotmánybíróság is több esetben foglalkozott. Az 53/2011. (VI. 24.) számú AB-határozatában megerősítette, hogy „.... helyi társadalmi viszonyok között fontos szerepet töltenek be az Ét. felhatalmazása alapján alkotott helyi építésügyi szabályzatok és a településrendezési tervek, miután ezek az adott település és környezete fejlődését, a településen élők, ott-tartózkodók életkörülményeit hosszabb időszakra döntően befolyásolják. Ebböl is következik, hogy a helyi építésügyi elöírásoknak több követelménynek kell eleget tenniük... Mind-

23 JNO-457/2011. számú Állásfoglalás a településrendezési eszközök környezeti vizsgálatának érvényesítéséről.

24 A terv és program fogalompár értelmezése, illetve eleve az SKV-irányelv céljának elemzése az Európai Bíróság számára is megmagyarázandó kérdésként szerepel a C-105/09 és C110/09 sz. egyesített ügyekben, azaz az úgynevezett Terre Wallone-ügyben. Az ítélet rendelkező része szerint „A vizek mezőgazdasági eredetü nitrát szennyezéssel szembeni védelméről szóló, 1991. december 12-i 91/676/EGK tanácsi irányelv 5. cikkének (1) bekezdése alapján elfogadott cselekvési program föszabály szerint az SKV irányelv 3. cikke (2) bekezdésének a) pontjában említett tervnek vagy programnak minősül, mivel ezen utóbbi irányelv 2. cikkének a) pontja értelmében vett »tervnek v vagy "programnak« tekintendö, és mivel olyan intézkedéseket tartalmaz, amelyeknek a betartásától függ az 1997. március 3-i 97/11/EK tanácsi irányelvvel módosított, az egyes köz- és magánprojektek környezetre gyakorolt hatásainak vizsgálatáról szóló, 1985. június 27-i 85/337/EGK tanácsi irányelv I. és II. mellékletében felsorolt projektek megvalósítására vonatkozó engedély megadása." Az ítélet maga tehát egy igen egyszerű fogalmi elemzés alapján döntött a cselekvési program SKV-irányelv hatálya alá tartozásáról, a kérdést illetően több információt ad még a főtanácsnoki indítvány. 
ezekre tekintettel az Ét. részletesen szabályozza [...] a helyi épitésügyi szabályzat és a településrendezési tervek kidolgozása során érvényesítendő eljárási szabályokat, rendezi, hogy az érintett állampolgárokat, szervezeteiket, államigazgatási szerveket, települési önkormányzatokat milyen tartalommal, milyen módon, határidőben kell tájékoztatni, véleményüket kérni, véleményeltérés esetén egyeztető tárgyalást tartani, az el nem fogadott véleményekről tájékoztatást adni" (ABH 2004, 853, 857.).

Az Étv. 9. § (7) bekezdése szerint a helyi építési szabályzat és a településrendezési tervek a (2)-(6) bekezdésben elöírt véleményeztetési eljárás lefolytatása nélkül nem fogadhatók el. Ahogy az Alkotmánybíróság a 7/2003. (III. 13.) AB-határozatában megállapította, „az önkormányzatok városrendezésre és épitésügyre vonatkozó szabályozási autonómiája kizárólag a rendeletalkotás tartalmát és az alkalmazott eljárás lefolytatását meghatározó törvényi keretek között érvényesülhet. llyen, az önkormányzati rendeletalkotás során irányadó eljárási rendelkezéseket állapít meg az Étv. [...], amikor a helyi épitési szabályzat elfogadásához a közérdek érvényesitése érdekében számos egyeztetési kötelezettséget ír elö, és az érintett állampolgárok, szervezetek, érdekképviseletek, hatóságok számára véleménynyilvánítási, javaslattételi, észrevételezési lehetőséget biztosít" (ABH 2003, 753, 756.). Az érdekelt államigazgatási szervekkel való egyeztetés kötelezettsége és a lakosság bevonása az eljárásba olyan garanciális jellegű eljárási követelményeket jelent, amelyeket a jogi szabályozás nem ír elö más önkormányzati rendelet megalkotása során.

E garanciális jogalkotási folyamat egészül ki többek között az SKV-rendelet által szabályozott stratégiai környezeti vizsgálattal. Ennek indoka abban keresendő, hogy a településrendezés esetén olyan folyamatról beszélünk, mely a lakosság életkörülményeit alapjaiban érinti, így a településrendezés céljait és hatásait környezeti szempontból értékelő stratégiai környezeti vizsgálat a jogalkotási hatásvizsgálat egy kiemelten fontos és jellegét tekintve speciális módszerének tekinthető.

\subsubsection{A stratégiai környezeti vizsgálat gyakorlati alkalmazása}

Miként azt már említettem, a magyar jogalkotó a Kvt. módosításával és az SKVrendelet megalkotásával megfelelően eleget tett transzpozíciós kötelezettségeinek, ugyanakkor a jogszabályok gyakorlati alkalmazása kérdéses. Ez indokolható egyrészt azzal, hogy a tervek és programok kidolgozóinak, így például a helyi önkormányzatok képviselö-testületeinek nincsenek teljes körü ismereteik a jogszabályi követelményeket illetően, utalni kell ugyanakkor arra is, hogy a kidolgozásért felelős szervek egy része jelentős ellenállást tanúsít a stratégiai környezeti vizsgálat szükségességével kapcsolatosan. ${ }^{25}$

25 Az önkormányzatok elutasító magatartásának jó példáját adja a budapesti agglomeráció egyik megyei jogú városának véleménye, melyben az önkormányzat a település területét egészében érintő településszerkezeti terv módosításával kapcsolatos ombudsmani megkeresésre adta az alábbi választ: „Fentiek alapján megállapitható, hogy a hatályos településszerkezeti terv felülvizsgálatának jóváhagyandó és alátámasztó munkarészei egyértelmüen igazolják, hogy a településszerkezeti tervi módosítások a város környezetminőségére káros hatással nincsenek, illetve nem lesznek, sőt a tervi javaslatok többsége a város környezetminőségének javulását szolgálják. ĺgy a 2/2005. (I. 11.) Kormány rendelet szerinti külön környezeti vizsgálat és értékelés elkészítése nem szükséges, mivel az legfeljebb a tervezési folyamatot hosszabbítaná meg, 
2009-ben a Jövő Nemzedékek Országgyűlési Biztosának Irodája átfogó kutatást indított, amelynek részeként elemezte az irányelvnek való megfeleléssel kapcsolatos jogalkotási követelmények teljesülését, a rendelet gyakorlati alkalmazását, az érintett jogalkalmazó és jogalkotó szervek ismereteit az új jogintézményt illetően, valamint a közigazgatási szervek kifogásait e jogszabály alkalmazására vonatkozóan. A kutatás alapját az Iroda által elkészített megkeresések képezték, melyek alapján valamennyi fővárosi kerület, a Fővárosi Önkormányzat és Nyíregyháza, Debrecen, Szeged, Pécs, valamint Sopron megyei jogú városok közgyűlése fejtette ki véleményét a kérdéssel kapcsolatosan. A válaszok összegzése alapján kirajzolódó konfliktusos területek közé tartozik a rendelet hatályának kérdése (mely tervek és programok esetén kötelező SKV készítése?), az SKV készítésével kapcsolatos eljárás viszonya a településrendezési eljárásokhoz, valamint az SKV elmulasztásának szankcionálhatósága. ${ }^{26}$

A válaszok ismeretében elmondható, hogy a fővárosi kerületek álláspontja szerint a kerületre vonatkozó településrendezési eszközök készítésénél nem szükséges az SKV, azt a Fővárosi Önkormányzat keretszabályozásánál, településszerkezeti tervénél látják szükségesnek. Hivatkoznak arra, hogy az országos településrendezési és építési követelményekről szóló 253/1997. (XII. 20.) Korm. rendelet (a továbbiakban: OTÉK) 3. § (3) bekezdése alapján környezetvédelmi munkarész készül, melyet a környezetért felelős szervek véleményeznek. Ezért úgy vélik, hogy a környezetvédelmi hatóság feladata, hogy jelezze az önkormányzatnak, amennyiben szükségesnek tartja az SKV elvégzését.

Az önkormányzatok egy része - azokban az esetekben, amikor eseti mérlegelés alapján dönthető el, hogy van-e olyan jelentős hatás, ami miatt szükséges a környezeti vizsgálat - konkrét kérdéssel fordul a rendeletben meghatározott szervekhez, a beérkezett vélemények alapján pedig döntést hoz a vizsgálat elkészítéséröl vagy mellőzéséről. Az önkormányzatok egyöntetüen úgy gondolják, hogy a környezetvédelmi szervek feladata, hogy a környezetvédelmi szempontok hatékony érvényre juttatása érdekében jelezzék, hogy milyen vizsgálatok elvégzését tartják szükségesnek.

Az eljárási kérdések lényegi pontját az egyes eljárási fokozatok egymáshoz való igazítása jelenti. A településrendezési eszköz elfogadásának folyamata öt részből áll. Ezek az előkészítés és előzetes véleményezés, a dokumentumkidolgozás, a közbenső véleményezés, a záró véleményezés, valamint az önkormányzati elfogadás. Ehhez többé-kevésbé igazodik az SKV-készítés folyamata, mely az előkészítés (a környezeti vizsgálat szükségességének megállapítása), kidolgozás (tematika, környezeti értékelés készítése és az országhatáron átterjedő hatások vizsgálata), véleményezés, valamint a döntéshozatal és tájékoztatás lépéseiből áll.

Az SKV-rendelet által előirt stratégiaivizsgálat-készítési kötelezettség és az említett településrendezési véleményeztetési eljárás egymáshoz való viszonya nincs

de a tervet koncepcionálisan érintő új környezetvédelmi konfliktusokat nem tárhatna fel, illetve a terv egyes munkarészeihez megfogalmazott környezetvédelmi követelményeket, javaslatokat érdemben nem egészíthetné."

26 E kérdéseket is érinti a JNO-457/2011. számú állásfoglalás, mely a településrendezési eszközök környezeti vizsgálatának érvényesítéséről szól. 
tökéletesen rendezve, amennyiben az egyes fázisokhoz kapcsolódó határidőkre a jogszabályok több ponton inkonzisztens, egymáshoz nem illeszkedő rendelkezéseket írnak elő. Aggályokat vet fel az is, hogy azok az SKV-eljárási lépések, melyeknek nem található megfelelő párja a településrendezési eljárás lépései között, sok esetben kimaradnak. Az SKV-rendelet által szabályozott eljárás kell, hogy környezetvédelmi szempontból a településrendezési eljárások alapját szolgáltassa, hogy annak stratégiai szemléletmódja valóban érvényesülhessen. Problémaként jelentkezik az a gyakorlat is, hogyha a környezetvédelmi szerv „hiánypótlást” ír elö, és egyúttal nem ad véleményt, akkor a véleménye nélkül fogadják el a településrendezési eszközt, az ily módon elfogadott településrendezési eszközben pedig nem érvényesülnek a környezetvédelmi szervek által képviselt környezetvédelmi szempontok. Ez a későbbiekben, a településrendezési terv alapján lefolytatni kívánt beruházások engedélyezési eljárásai során azzal a következménnyel járhat, hogy ebben a fázisban tagadja meg hozzájárulását a környezetvédelmi hatóság, ezzel akár a beruházás megvalósulását is kizárva.

Ez alapján nyilvánvaló, hogy az előirt környezeti vizsgálat lefolytatása a beruházás teljes spektrumát figyelembe véve a beruházónak ugyanúgy érdeke, hiszen ezáltal a stratégiai tervezés részeként lehet tisztázni az esetleges, a településrendezés szintjén feltárható és értékelhető környezeti konfliktusokat, illetve azok megoldási lehetöségeit, és így nem a konkrét engedélyezési eljárásban kell megoldani azon vitás kérdéseket, melyek a megelőzés követelményét érvényesítve már a tervezési eljárásban rendezhetők lennének.

A tapasztalatok szerint a települési önkormányzatok és a tervezök nem tartják jelentősnek a környezeti vizsgálatot, azt leginkább az eljárást hátráltató, költségnövelő tényezőként értékelik, sőt a tervezők a rendezési tervek kidolgozásának metódusába sem igazán építették be. Ebböl következik az előzőekben bemutatott esetkör is, amikor csak utólag, mintegy „hiánypótlásként” nyújtják be a vizsgálati anyagot, ekkor viszont jelentős mértékben tapasztalható párhuzamosság a környezeti vizsgálat és az egyéb alátámasztó munkarészek anyagai között.

A tervezők visszajelzése szerint nehézséget jelent, hogy a tervezett fejlesztési szándékok mögött a rendezési tervek készítésekor még nem áll rendelkezésre elegendő konkrétum ahhoz, hogy komplex vizsgálatokat végezzenek. Egy-egy terület, pl. tervezett ipari vagy gazdasági célú hasznosítása esetén, az előzetes vizsgálat során is sokszor nehézséget jelent a várható hatások becslése, vizsgálata, a hatásterület meghatározása. Az eddigi tapasztalatok azt mutatják, hogy a települési önkormányzatok hivatalainak dolgozói nem ismerik megfelelően a rendelet tartalmát, és ezért sem a nyilvánosság és az államigazgatási szervek bevonásával, sem a meghatározott önkormányzati döntésekkel kapcsolatban a jogszabályi előírások nem érvényesülnek megfelelöen. Többnyire arról sem érkezik visszajelzés a környezetvédelmi szervhez, hogy az adott települési önkormányzat nem tartja szükségesnek a környezeti vizsgálat lefolytatását. Sajnos „csupán” a tervező, kidolgozó szemléletén, környezettudatosságán múlik, hogy a környezeti vizsgálat milyen részletességgel, tartalommal készül.

Említést kell tenni az SKV készítésével kapcsolatos kötelezettségek elmulasztásának szankcionálhatóságáról is. Alapvetően meghatározza a helyzetet, hogy a kör- 
nyezetvédelmi hatóság ebben az eljárásban mindössze véleményezőként vesz részt, tehát nem kötelezheti az önkormányzatot megfelelő környezeti vizsgálat elkészítésére. A környezetvédelmi szerv eljárásbeli szerepét szükséges lenne erősíteni, vagyis meg kell vizsgálni annak lehetőségét, hogy miként lehet a stratégiai környezeti vizsgálat jogszabályoknak megfelelő tartalommal történő lefolytatását hatékonyabban elősegíteni.

Ami az alkalmazható szankciókat illeti, utalni kell arra, hogy 2012. január 1-jétől több szempontból változott a jogi környezet. 2012. január 1-jét megelőzően a Magyar Köztársaság Alkotmányáról szóló 1949. évi XX. törvény és a helyi önkormányzatokról szóló 1990. évi LXV. törvény alapján az Alkotmánybíróság általi felülvizsgálat lehetősége volt biztosítva alkotmányellenes helyi jogalkotás esetén. Ebbe a kategóriába sorolhatók a helyi építési szabályzatok és az ahhoz kapcsolódó, már hivatkozott AB-gyakorlat, mely különös figyelmet fordít az Étv. 9. §-a szerinti eljárási követelmények betartására. Az SKV elmaradásával, mint akár formai, akár tartalmi követelménnyel, az Alkotmánybíróság érdemben egy döntésében sem foglalkozott. Mindebből adódóan az SKV lefolytatása leginkább a helyi önkormányzatok jogkövető magatartására volt bízva, amit a közigazgatási hivatalok, majd pedig a kormányhivatalok ellenőriztek.

2012. január 1-jén hatályba lépett az Alaptörvény, melynek 25. cikk (2) bekezdés c) pontja kimondja, hogy a bíróság dönt az önkormányzati rendelet más jogszabályba ütközéséről és megsemmisítéséről. A bíróságok szervezetéről és igazgatásáról szóló 2011. évi CLXI. törvény (a továbbiakban: Bszi.) 24. § (1) bekezdés f) pontja szerint a Kúria dönt az önkormányzati rendelet más jogszabályba ütközéséröl és megsemmisítéséről. Az Alkotmánybíróságról szóló 2011. évi CLI. törvény 37. § (1) bekezdése szerint az $\mathrm{AB}$ az önkormányzati rendelet Alaptörvénnyel való összhangját akkor vizsgálja, ha a vizsgálat tárgya az önkormányzati rendelet más jogszabályba ütközésének vizsgálata nélkül, kizárólag az Alaptörvénnyel való összhang megállapítása. Tekintettel arra, hogy a településrendezési eljárások jogellenessége jellemzően törvénysértésben nyilvánul meg, a bíróság, konkrétan a Kúria feladata lesz ezen szabályok alkalmazása. E megoldás, melynek értelmében a kormányhivatal bírósági eljárást kezdeményezhet, új lehetőségeket teremt a joggyakorlat fejlesztésére, így például annak kimondására, hogy az SKV-rendelet szabályait, az Étv. mellett valóban figyelembe kell venni, a településrendezési eljárások kötelező és garanciális elemeként. Az új szabályok gyakorlati hatásának értékeléséhez szükségesek a Kúria ilyen tárgyban hozott határozatai, ezek száma azonban jelenleg csekély. ${ }^{27}$

27 Elöremutató viszont, hogy a Kúria több környezetvédelmi tárgyú ügyben hozott döntést, az egyik ügyben pedig konkrétan foglalkozott a Natura 2000 területekkel kapcsolatos előzetes hatásbecslési eljárással, valamint a stratégiai környezeti vizsgálat lefolytatásával. Köf.5.023/2012/9. számú határozat. 


\section{Zárógondolatok}

A magyar jogalkotás hatásvizsgálati eszköztára sok ponton fejlődött az elmúlt évek jogalkotási gyakorlatához képest, azonban a minőségi jogalkotás céljának eléréséhez sokat kell még tenni. Az új Jat. hatálybalépésével lehetőség nyílik a korábbinál sokkal modernebb és hatékonyabb, a XXI. század követelményeinek jobban megfelelő hatásvizsgálati rendszer kialakítására. Az új Jat. által meghatározott kereteket a hatásvizsgálati rendelet, valamint a hatásvizsgálati útmutató tölti meg tartalommal, mely a korábbinál jóval részletesebb szabályokat ad a jogalkotó számára. Jelentős az elörelépés a környezeti hatásvizsgálatokkal kapcsolatban is, mint pl. a fenntartható fejlődés követelményének bevezetése a hatásvizsgálati rendszerbe. Nem szabad azonban szem elöl téveszteni, hogy jelenleg még inkább csak a fogalom bevezetéséről beszélhetünk, mivel a fenntarthatósági szempontok a hatályos szabályozásban megfeleltethetök a környezet- és természetvédelmi szempontoknak, tehát a fenntarthatóság gazdasági, társadalmi és környezeti szempontjait a jogalkotó nem integrálta, így a rendszer nem jelenít meg átfogó érték- és követelményrendszert.

Az előrelépés intézményi szempontból is jelentős, amennyiben az újonnan kialakított Nemzeti Környezetügyi Intézet (a továbbiakban: NeKI) mint a vidékfejlesztési miniszter irányítása alá tartozó hivatal, fontos feladatokat kapott a környezeti hatásvizsgálatok lefolytatásában. A környezetvédelmi, természetvédelmi, vízügyi hatósági és igazgatási feladatokat ellátó szervek kijelöléséről szóló 347/2006. (XII. 23.) Korm. rendelet 33/A. § (2) bekezdés 12. pontja szerint a NeKI közremüködik a jogszabályokhoz kapcsolódó előzetes és utólagos hatásvizsgálatok, valamint háttéranyagok elkészítésében. A NeKI küldetése tehát, hogy a kormányzati szereplőkkel és a civil szereplőkkel együttmüködve alapozza meg a hatékony jogalkotást.

A hatásvizsgálati rendszer átalakítása új lehetőségeket hozott létre, ezek kihasználása a jogalkotó szerepfelfogásától függ, azonban a kiindulási alap sok tekintetben elöremutató. Ehhez társulhat az Európai Unió nyugati tagállamainak, illetve az attól bizonyos fokig eltérő értékrendet valló, azonban sok szempontból értékes amerikai gyakorlatnak a megismerése és megértése, ami szükséges ahhoz, hogy a megfelelő mintát kiválasztva, azt a nemzeti sajátosságokhoz igazítva alakíthassuk ki, és fejleszthessük saját jogalkotási rendünket.

\section{Abstract}

The study deals with the system of the impact assessment of environmental legislation in Hungary. The system can be divided into three parts, these are the environmental aspects of general impact assessment, the environmental impact assessment of legislation and the strategic environmental assessment. The aim of the study is to evaluate these tools and to draw up the possible ways of legal interpretation and development. The study offers an evaluation of the theoretical basis with consideration to a practice-oriented approach. 